\title{
Turkish Adaptation of Khalfa Hyperacusis Questionnaire
}

\author{
Khalfa Hiperakuzi Ölçeğinin Türkçeye Uyarlanması
}

\author{
Murat ERINC $\odot$, Ufuk DERINSU $\odot$
}

Ethics Committee Approval: This study was approved by Marmara University Institute of Health Sciences Ethics Committee, 28 March.2016-2016/31

Conflict of interest: The authors declare that they have no conflict of interest.

Funding: None.

Informed Consent: Informed consent was taken from the patients enrolled in this study.
Cite as: Erinc $M$, Derinsu $U$. Turkish adaptation of khalfa hyperacusis questionnaire. Medeniyet Med J. 2020;35:142-50.

\begin{abstract}
Objective: The aim of this study is to adapt Khalfa Hyperacusis Questionnaire (HQ) into Turkish for the use in the diagnosis and treatment of patients with hyperacusis.

Method: HQ and Beck Anxiety Inventory (BAI) were administered to a total of 529 participants (320 female, 209 male), aged 18 to 73 (mean age: 29.76 10.59 ) years who were randomly selected from the general population. For the evaluation of the data, confirmatory and exploratory factor analysis, correlation analysis, descriptive statistics, $t$-test, analysis of variance, and Sidak correction test were used.

Results: In the reliability analysis, the Cronbach's alpha $(\alpha C)$ internal consistency coefficient was found to be 0.81. Factor analysis revealed three subdimensions (attentional, social, and emotional). The total variance of these three subdimensions were $63 \%$, and the internal consistency of the subdimensions was also high $(\alpha \mathrm{C}>0.70)$. Confirmatory factor analysis and structural equation modeling results indicated that three-factor solutions with 14 items met the criteria for the adequacy of fit among the Turkish patients. The mean score for hyperacusis was estimated as $15.69 \pm 6.63$ points. There was a positive, weak, but significant association between hyperacusis and anxiety $(r=0.357, p=0.01, p<0.05)$. The patients who were exposed to noise were found to have higher levels of hyperacusis, compared to those who were not $(t=6.78, p=0.01, p<0.05)$. The patients who had decreased noise tolerance over time were found to be higher hyperacusis levels than those without ( $t=4.83, p=0.01, p<0.05)$.

Conclusion: Based on these measurements, 14 questions and three-factor solutions were found to be a valid and reliable tool.
\end{abstract}

Keywords: Hyperacusis, scale adaptation, auditory hyperesthesia, Khalfa Hyperacusis Questionnaire, Beck Anxiety Inventory

\section{öz}

Amaç: Bu çalışmada hiperakuzili hastaların tanı ve tedavilerinde kullanılmak üzere Khalfa Hiperakuzi Ölçeği'nin Türkçeye uyarlanması amaçlandı.

Yöntem: Genel popülasyondan rastgele seçilmiş 18-73 yaş arası $(M=29 ., 6, S D=10,59)$ toplam 529 kişiye (320 kadın, 209 erkek) Türkçeye çevrilen Khalfa Hiperakuzi Ölçeği ve Beck Anksiyete Ölçeği uygulandı. Verilerin değerlendirilmesinde açımlayıcı ve doğrulayııı faktör analizi, korelasyon analizi, tanımlayıcı istatistiksel yöntemler, $t$-testi, varyans analizi ve Sidak testi kullanıldı.

Bulgular: Yapılan güvenirlik analizinde Cronbach alfa $(\alpha C)$ iç tutarlılık katsayısı 0,81 olarak tespit edildi. Faktör analizi sonucunda ise, üç adet alt boyut (dikkat, sosyal ve duygusal) tespit edilmiştir. Bu üç alt boyutun toplam varyansı \%63 olarak bulundu ve alt boyutların iç tutarlılığı yüksek elde edildi $(\alpha C>0,70)$. Doğrulayıcı faktör analizi ile yapılan uyum istatistiklerinin Türk hastalardan toplanan gerçek verilerle kabul edilebilir düzeyde uyumlu olduğu görüldü. Hiperakuzi puanın ortalaması 15,69 (₫6,63) olarak saptandı. Hiperakuzi ile anksiyete arasında pozitif yönde, düşük düzeyde güçlü ve anlamlı bir ilişsi olduğu tespit edildi $(r=0,357, p<0,05)$. Gürültüye maruz kalan hastaların hiperakuzi düzeylerinin, gürültüye maruz kalmayan hastalara klyasla, daha yüksek olduğu görüldü $(t=6,78, p<0,05)$. Zamanla gürültüye olan tahammüllerinde azalma olan hastaların hiperakuzi düzeyleri, olmayanlara kıyasla, daha yüksek bulundu $(t=4,83, p<0,05)$.

Sonuç: Yapılan ölçümler sonucunda 14 soru ve üç faktörlü yapının geçerli ve güvenilir bir araç olduğu sonucuna varıldı.

Anahtar kelimeler: Hiperakuzi, ölçek uyarlama, işitsel aşırı hassasiyet, Khalfa Hiperakuzi Ölçeği, Beck Anksiyete Ölçeği

(c) Copyright Istanbul Medeniyet University Faculty of Medicine. This journal is published by Logos Medical Publishing.

Licenced by Creative Commons Attribution-NonCommercial 4.0 International (CC BY-NC 4.0)
Received: 7 April 2020

Accepted: 10 May 2020

Online First: 30 June 2020

Corresponding Author: M. Erinc

ORCID: 0000-0003-2762-0173

Istanbul Medeniyet University,

Faculty of Health Sciences,

Department of Audiology, Istanbul, Turkey

murat.erinc@medeniyet.edu.tr

U. Derinsu

ORCID: 0000-0003-0438-0074

Marmara University,

Faculty of Medicine,

Department of Audiology, Istanbul, Turkey 


\section{INTRODUCTION}

Hyperacusis has no single common definition. The situation has become difficult for patients, clinicians, and researchers due to its different definitions. According to the contemporary definition, hyperacusis in an individual with mostly normal hearing thresholds is intolerance to everyday sounds from the environment, which do not disturb other individuals ${ }^{1-3}$. Some authors that have focused on emotional status caused by hyperacusis have used the terms phonophobia (fear of sound) ${ }^{4}$ and misophonia (dislike of sound) ${ }^{5}$. Hyperacusis, phonophobia, and misophonia are subjective symptoms that resemble each other, and differentiation is difficult. In a review study, Tyler et al. ${ }^{6}$ examined different definitions and the contemporary approach, and to avoid the confusion in the diagnosis and treatment, they divided hyperacusis into four categories as loudness, annoyance, fear, and pain.

The scales used in the diagnosis and treatment of hyperacusis are of particular importance. The Hyperacusis Questionnaire $(\mathrm{HQ})^{3}$, Multiple Activity Scale for Hyperacusis (MASH) ${ }^{7}$, and Questionnaire on Hypersensitivity to Sound (GÜF - Geräuschüberempfindlichkeit) ${ }^{8}$ are the most commonly used scales in the measurement of hyperacusis. MASH has been prepared in an interview format to be administered particularly to patients with tinnitus and this scale aims at measuring hyperacusis by asking patients their discomfort/distress in 15 different settings and activities (cinema, concert, work environment, driving, restaurant, etc.). GÜF was translated from German into English and validated by Bläsing et al. ${ }^{9}$, and this tool similarly measures subjective discomfort caused by sensitivity to sound. Khalfa et al. ${ }^{3}$ suggested that reactions to discomforting sound must be evaluated with regards to behavioral/adaptive, cognitive, and emotional aspects. The questions in $\mathrm{HQ}$ have been prepared in this context in anticipation of examining hyperacusis under these three subheadings. That would pro- vide efficient evaluation in terms of diagnosis and treatment. The scale was administered to 201 individuals without applying any inclusion criteria, as the applicability of the scale on general population was investigated. The principal component analysis has produced three components (attention, social, and emotional dimensions). The total score in the scale is $\mathbf{4 2}$ points, and subjects scoring 28 points and above are considered to have hyperacusis.

In the present study, we aimed to adapt the hyperacusis scale developed by Khalfa et al. ${ }^{3}$ into Turkish language. We also evaluated the clinical usability of the Turkish version by assessing the validity and reliability of the scale to identify the subjects with and without hyperacusis based on their scores on this scale.

\section{MATERIALS AND METHODS}

\section{Study population}

In the present study, there were 529 participants (320 females and 209 males) recruited between January 2016 and August 2016. The ages of the participants ranged between 18 and 73 (mean: $29.76 \pm 10.59$ ) years. The participants were recruited using two methods. Some $(n=104)$ participants were recruited among Marmara University School of Medicine students and their friends and families. Ten of them were having hyperacusis complaints and seeking help. The other group consisting of 425 participants was recruited through Facebook and Twitter. Participants aged 18 years or over were included in the study and no other inclusion or exclusion criteria were applied, as the study investigated the applicability of the Turkish version of the scale on the general population.

In the original study of Khalfa et al. ${ }^{3}$, an average score of $14.97 \pm 6.79$ was obtained on 201 participants on general population. In the present study, it was observed that the average score of 529 participants was $15.69 \pm 6.63$. The power calculated over these average scores was found to be 0.99 
and the effect size was 0.43 . The study was found to have sufficient power.

The study was approved by the Marmara University Institute of Health Sciences Ethics Committee and conducted in accordance with the principles of the Declaration of Helsinki. A written informed consent was obtained from each participant.

\section{Data Collection Tools}

Two scales were used in the present study. The first scale is Khalfa Hyperacusis Questionnaire (HQ), which is the primary focus of the present study. The other scale is Beck Anxiety Inventory $(\mathrm{BAI})^{10}$ that was used for the relationship between hyperacusis and anxiety. The Beck Anxiety Inventory was adapted to Turkish by Ulusoy et al. ${ }^{11}$. The Turkish adaptation of the scale has been found to have adequate reliability and validity. This inventory was completed by the participants providing consent for the study both in written and on the online form.

\section{Translation and Cultural Adaptation of the Questionnaire}

The questionnaire was translated from English to Turkish by four translators and two of them are native speakers of Turkish, bilingual in English. Translators have independently translated the original questionnaire into Turkish with the permission of the author. Afterward, we formed the pooled version that was then reviewed for the linguistic quality. The translated questions were initially applied to a group of fifteen participants; the eighth question's examples are adapted culturally by removing "cocktail receptions" and adding "weddings" to maintain content integrity. This version was translated into English via a systematic forwardbackward translation process and compared with the original questionnaire. The latest Turkish version of the questionnaire was administered to the participants (Appendix 1).

\section{Khalfa Hyperacusis Questionnaire}

The HQ is composed of two sections. The first section contains three questions inquiring previ- ous noise exposure and general information about hearing. The second section contains 4-point Likert-type 14 questions. This section has attentional (questions 1-4), social (questions 5-10), and emotional (questions 11-14) dimensions. Only the second section of the questionnaire is scored $(\mathrm{No}=0$ points; Yes, a little $=1$ point; Yes, quite a lot $=2$ points; $A$ lot $=3$ points). The scores of the responses are summed. The maximum total score is 42 points. A score of $\geq 28$ indicates hyperacusis.

\section{Beck Anxiety Inventory}

The BAI is composed of 21 items. This inventory is a Likert-type self-assessment tool. Each item is rated from 0 to 3 points (Not at all= 0 points; Mildly, but it didn't bother me much $=1$ point; Moderately - it wasn't pleasant at times $=2$ points; Severely - it bothered me a lot= 3 points). The anxiety level is measured based on the total score on this scale (0-7 points $=$ minimal, $8-15$ points $=$ mild anxiety, 16-25 points $=$ moderate anxiety, 26-63 points $=$ severe anxiety).

\section{Statistical Analysis}

Statistical analysis was performed using the SPSS 22.0 software package and AMOS 23.0 (IBM Corp., Armonk, NY, USA). Descriptive statistics included frequency, percentage, mean, and standard deviation. Exploratory factor analysis (EFA) was used to uncover the structure of the scale dimensions, and confirmatory factor analysis (CFA) was used to determine the factor structure. Cronbach's alpha analysis was used to test internal consistency of subdimensions and reliability of the scales. One-Sample Kolmogorov-Smirnov (K-S) test was used to see whether the data was normally distributed. T-test was used to analyze the difference between measurements of two groups in the subdimensions. Analysis of variance (ANOVA) was used to compare three groups and Sidak test was used in paired comparisons (post-hoc). Correlation analysis was performed to test the relationship between subdimensions. A p value of less than 0.05 was considered statistically sig- 
nificant. Power and effect size calculations were determined with $G^{*}$ Power Version 3.1.7.

\section{RESULTS}

\section{Results of Reliability and Validity Analyses}

The HQ was found to be a considerably reliable tool based on the results of Cronbach's alpha analysis that was performed to evaluate the reliability of 14 items of the scale (Cronbach's alpha value of .81). As a result, no item was omitted from the scale. After controlling for the test reliability, factor analysis was performed to determine subdimensions.

Three subdimensions were identified according to the factor analysis. This includes attentional, social, and emotional subdimensions (Table 1). The Kaiser-Meyer-Olkin (KMO) coefficient was 0.81 in factorial analysis that calculated the adequacy of sampling. This coefficient indicates that 529 participants are adequate to reveal the construct of subdimensions (a $\mathrm{KMO}>0.70$ is adequate for factor analysis). Furthermore, the acquired dimensions are structurally significant according to the Bartlett test evaluating the significance of factor structures $\left(X^{2}=4507,22 p=0.01, p<0.05\right)$

Table 1. Evaluation of the Validity of Khalfa Hyperacusis Questionnaire.

\begin{tabular}{lllll}
\hline Items & \multicolumn{2}{c}{$\begin{array}{l}\text { Factor } \\
\text { Loading }\end{array}$} & $\begin{array}{c}\text { Eigenvalue } \\
\text { Eariance } \\
\text { Explained }\end{array}$ & $\begin{array}{l}\text { Internal } \\
\text { Consistency }\end{array}$ \\
\hline Q1 attention & 0.580 & 4.250 & $26 \%$ & 0.75 \\
Q2 attention & 0.573 & & & \\
Q3 attention & 0.855 & & & \\
Q4 attention & 0.881 & & & \\
Q5 social & 0.521 & 2.5 & $20 \%$ & 0.77 \\
Q6 social & 0.474 & & & \\
Q7 social & 0.646 & & & \\
Q8 social & 0.807 & & & \\
Q9 social & 0.761 & & & \\
Q10 social & 0.886 & & & \\
Q11 emotional 0.964 & 1.98 & $17 \%$ & \\
Q12 emotional 0.924 & & & \\
Q13 emotional 0.949 & & & \\
Q14 emotional 0.944 & & & \\
\end{tabular}

The three subdimensions are able to explain 63\% of total variance contained in the data. When the subdimensions are evaluated individually, attentional dimension explains $26 \%$ of total variance, yielding an internal consistency of .75. Social dimension explains $20 \%$ of total variance, yielding an internal consistency of .77. Emotional dimension explains $17 \%$ of total variance, yielding an internal consistency of .73. The analysis showed that 14 expressions in the HQ have met the conditions for reliability and structural validity ${ }^{12}$.

The analysis of the goodness of fit following factor analysis yielded a $\mathrm{X}^{2} / \mathrm{df}$ value of 3.899 and this value indicates a very good model fit. The Goodness of Fit Index (GFI) was 0.91, Adjusted Goodness of Fit Index (AGFI) was 0.882, Root Mean Square Residual (RMR) was 0.03, Root Mean Square Error of Approximation (RMSEA) was 0.068. The goodness of fit statistics calculated by the confirmatory factor analysis showed that the model was consistent at an acceptable level with the real-life data obtained from the Turkish participants. Based on these results, the results of confirmatory factor analysis were found to be valid in determining the structural validity of the scale $\mathrm{e}^{12,13}$.

\section{Questionnaires}

The mean hyperacusis score of the study participants was $15.69 \pm 6.63$ points. There was a low but significantly positive (linear) correlation between the HQ and BAI $(r=0.37, p<0.01)$. The relationship between the severity of anxiety and hyperacusis scores is shown in Table 2.

Table 2. Khalfa Hyperacusis Questionnaire Scores and Anxiety Level According to Beck Anxiety Inventory.

\begin{tabular}{lllllll}
\hline $\begin{array}{l}\text { Beck Anxiety } \\
\text { Inventory }\end{array}$ & $\mathbf{n}$ & $\mathbf{X}$ & SD & $\mathbf{F}$ & $\mathbf{p}$ & $\begin{array}{l}\text { Paired } \\
\text { Comparison }\end{array}$ \\
\hline Low (1) & 187 & 13.34 & 6.17 & 20.69 & 0.01 & $1.2<3.4$ \\
Mild (2) & 150 & 15.42 & 6.00 & & & \\
Moderate (3) & 103 & 18.14 & 6.67 & & & \\
Severe (4) & 71 & 19.03 & 6.62 & & & \\
\hline
\end{tabular}

n: Sample Size; X: Hyperacusis score mean; Sd: Standard Deviation, $p$ : Significance.

The examination of the relationship between the scores of the participants in the HQ and the 
educational levels showed that participants with an educational level of high school or lower had lower hyperacusis scores compared with the participants with university or higher-level education $(F=2.63, p=0.02, p<0.05)$.

There was no significant relationship between hyperacusis scores of the participants and their ages $(\mathrm{r}=0.09, \mathrm{p}=0.61, \mathrm{p}>0.05)$.

Participants with a history of noise exposure had higher hyperacusis scores than those without a history of exposure $(t=6.78, p<0.05)$. Participants with decreasing tolerance to noise in time had higher hyperacusis scores than participants without any change in the tolerance to noise $(t=4.83$, $\mathrm{p}<0.05)$. Gender and history of hearing loss had no significant effect on the hyperacusis scores (Table 3).

Table 3. Relationship Between Khalfa Hyperacusis Questionnaire, Noise Exposure, Time-Tolerance Effect, Hearing Problem, Gender.

\begin{tabular}{|c|c|c|c|c|c|c|}
\hline $\begin{array}{l}\text { Khalfa Hyperacusis } \\
\text { Questionnaire }\end{array}$ & & $\mathbf{n}$ & $\mathbf{X}$ & SD & $\mathbf{t}$ & $\mathbf{p}$ \\
\hline \multirow[t]{3}{*}{ Noise Exposure } & Yes & 437 & 16.59 & 6.40 & 6.78 & 0.01 \\
\hline & No & 87 & 11.54 & 6.11 & & \\
\hline & & & & & 4.83 & 0.01 \\
\hline \multirow[t]{2}{*}{ Time Influence } & Yes & 366 & 16.69 & 6.46 & & \\
\hline & No & 154 & 13.69 & 6.48 & 1.73 & 0.08 \\
\hline \multirow[t]{2}{*}{ Hearing Impairment } & Yes & 74 & 16.97 & 7.09 & -0.14 & 0.88 \\
\hline & No & 450 & 15.54 & 6.54 & & \\
\hline \multirow[t]{2}{*}{ Gender } & Male & 209 & 15.64 & 6.59 & & \\
\hline & Female & 320 & 15.72 & 6.66 & & \\
\hline
\end{tabular}

n: Sample Size; X: Hyperacusis score mean; SD: Standard Deviation, $t$ : $t$ test, $p$ : Significance.

\section{Khalfa Hyperacusis Questionnaire and the Complaint of Hyperacusis}

The HQ was administered to ten patients presenting to our clinic with complaints of hyperacusis. The scores ranged from a minimum of 15 points to a maximum of 34 points. The mean score was 25.1 points.

\section{Interpretation of the Scores}

Khalfa et al. $^{3}$ suggested a 28 -point criterion by adding two standard deviations to the mean of total scores, while 29-point criterion is suggested for the Turkish version of the HQ. In addition to this suggestion, two categories were created as "suspected hyperacusis" in participants with 15 to 28 points, and "complete hyperacusis" in participants with 29 points and higher based on our study on patients with hyperacusis and studies in the literature. The data obtained from the present study are presented in Table 4.

Table 4. Hyperacusis results.

\begin{tabular}{lll}
\hline Hyperacusis group & n & $\%$ \\
\hline No hyperacusis (less than 15) & 233 & 44.0 \\
Suspected hyperacusis (15-28 points) & 279 & 52.7 \\
Complete hyperacusis (29 points or higher) & 17 & 3.2
\end{tabular}

\section{DISCUSSION}

A gradual increase has been observed in the number of patients presenting to our clinic with hyperacusis within the last few years. This increase can be attributed to the urban noise exposure, increasing number of patients with tinnitus presenting to the clinics, and increasing accessibility to health care services. There is an increasing demand for tools to be used to measure sound sensitivity in a growing patient population. The HQ is widely used in this field and it was translated into many different languages. The aim of the present study was to bridge the gap for a validated, standardized, simple, and psychometrically strong scale for use in the Turkish language. This study, therefore, evaluated the psychometric characteristics of the $H Q$.

The Turkish version of the HQ showed satisfactory internal consistency (Cronbach's alpha: .81) in the analysis. The authors did not feel the need to omit any item from the questionnaire. Following evaluation of reliability, factor analyses were performed to determine subdimensions and three dimensions were acquired. These were named as attentional, social, and emotional dimensions similar to that in the original scale. The three sub- 
dimensions explained $63 \%$ of total variance contained in the data (Table 1). The goodness of fit statistics calculated following confirmatory factor analysis showed that the model was consistent at an acceptable level with the real-life data obtained from Turkish participants. According to these results, exploratory and confirmatory factor analyses showed that the structure was valid.

It is difficult to reach patient groups diagnosed with hyperacusis due to uncertainty in the definition of hyperacusis. Thus, it seems more reasonable to measure sensitivity to sound in general and interpret the results according to the distribution of total score by applying the measurement to the whole population. Normal distribution of total score indicates that the scale is sensitive in differentiating participants from the general population. The mean value and standard deviation reported in the study by Khalfa et al. ${ }^{3}(14.97 \pm 6.79)$ are considerably similar to the data obtained from the Turkish version of the scale $(15.69 \pm 6.63)$. Therefore, 29-point criterion calculated according to the method proposed by Khalfa et al. ${ }^{3}$ can be suggested for use in the Turkish version of the questionnaire. The studies in the literature suggest that patients with a total score less than 28 points on the original scale might have different types of hyperacusis complaints and these patients must also be taken into consideration. In the study by Blomberg et al. ${ }^{14}$, when HQ was administered to the patients with Williams syndrome that were known to have high sensitivity to sound, only $13 \%$ of these patients met the 28 point criterion. In the study by Jüris et al. ${ }^{15}$, onethird of the patients suffering predominantly from hyperacusis achieved less than 28 points and the authors set the threshold to 24 points according to the results of descriptive statistics in their study. Fioretti et al. ${ }^{16}$ conducted a study on patients with tinnitus, and suggested that a score of 16 points must be determined as the criterion. In the study by Fackrell et al. ${ }^{17}$, there were only 19 patients with hyperacusis among 264 patients with tinnitus according to 28-point criterion. Meeus et al. ${ }^{18}$ reported that the majority of patients with tinnitus and hyperacusis achieved less than 28 points.

The Turkish version of the HQ was administered to 10 patients, who presented to our clinic complaining of hyperacusis and their scores ranged from 15 to 34 points with a mean score of 25.1 points. As the authors of the present study have shared the same concerns in the literature, classification as "suspected hyperacusis" and "complete hyperacusis" seemed reasonable considering the current analysis on patients with hyperacusis. The aim of the authors was to avoid underdiagnosing patients with hyperacusis and detect patients with various types of hyperacusis using the Turkish version of the $\mathrm{HQ}$.

When hyperacusis is categorized as loudness, annoyance, fear, and pain; the scale to be administered should be able to analyze this classification. However, misophonia and phonophobia are not regarded as hyperacusis due to various definitions in the literature. The term hyperacusis is used only to refer to loudness hyperacusis. However, the lack of a relationship between uncomfortable loudness level (ULL) and hyperacusis in some studies does not justify this usage ${ }^{16,18}$. The item "Do noise and certain sounds cause you stress and irritation?" in the HQ evaluates annoyance hyperacusis and the entity termed as misophonia. Baguley ${ }^{19}$ suggested that avoidance is the basic mechanism of hyperacusis. This causes a vicious cycle due to "homeostatic plasticity" and "gain control" mechanisms ${ }^{20,21}$. The items "Do you even turn down an invitation or not go out due to the noise you would have to face?" and "When someone suggests doing something (going out to the cinema, to a concert, etc.), do you immediately think about the noise you are going to have to put up with?" are used to evaluate avoidance in the $H Q$.

The examination of the relationship between the items in the first section of the scale and total hyperacusis score provides information about the na- 
ture of hyperacusis. Although it is hard to speculate on the observation of increasing hyperacusis scores with increasing educational level of the participants, this can be attributed to the changes in perception of normality or the changes in the level of awareness with increasing educational level.

The relationship between anxiety and hyperacusis emphasized in the study by Blaesing and KroenerHerwig $^{22}$ was also observed in the present study. The participants with lower scores in the BAI achieved lower hyperacusis scores, whereas participants with higher scores in the BAI achieved higher hyperacusis scores (Table 2). These findings support the results of other studies in the literature and indicate the effects of hyperacusis on the mood state s3-25. $^{2}$.

Exposure to noise is thought to be one of the most important factors associated with hyperacusis. There are studies in the literature highlighting exposure to noise coupled with increasing complaints of hyperacusis ${ }^{26,27}$. Similar to the literature, the present study found higher hyperacusis scores in participants with a history of exposure to noise (Table 3).

Participants with a decrease in tolerance to noise in time had higher hyperacusis scores $(t=3, p<0.05)$. This finding shows that sensitivity to sounds does not remain stable and may change in time. Additionally, findings of the study support the literature that there is lack of a relationship between hearing impairment and hyperacusis scores (Table $3)^{28,29}$.

There were only 10 patients with complaints of hyperacusis. With the increase in this number, it will be possible to have much information about the functionality of new diagnostic categories.

\section{CONCLUSION}

In conclusion, there is no established gold standard method in the measurement of hyperacusis. Detailed history taking is considerably important and the scales are appropriate tools in evaluating diversified characteristics of hyperacusis. The assessments in the present study showed that the scale containing 14 items and three-factor solutions is a valid and reliable tool for measuring hyperacusis.

\section{REFERENCES}

1. Vernon JA. Pathophysiology of tinnitus: a special case-hyperacusis and a proposed treatment. Am J Otol. 1987;8(3):201-2.

2. Klein AJ, Armstrong BL, Greer MK, Brown FR, 3rd. Hyperacusis and otitis media in individuals with Williams syndrome. J Speech Hear Disord. 1990;55(2):339-44. [CrossRef]

3. Khalfa S, Dubal S, Veuillet E, Perez-Diaz F, Jouvent R, Collet L. Psychometric normalization of a hyperacusis questionnaire. ORL J Otorhinolaryngol Relat Spec. 2002;64(6):436-42. [CrossRef]

4. Phillips DP, Carr MM. Disturbances of loudness perception. American Academy of Audiology. 1998;9:371-9.

5. Jastreboff $M M$, Jastreboff PJ. Decreased sound tolerance and tinnitus retraining therapy (TRT). Australian and New Zealand Journal of Audiology, The. 2002;24(2):74. [CrossRef]

6. Tyler RS, Pienkowski M, Roncancio ER, Jun HJ, Brozoski T, Dauman N, et al. A review of hyperacusis and future directions: part I. Definitions and manifestations. Am J Audiol. 2014;23(4):402-19. [CrossRef]

7. Dauman R, Bouscau-Faure F. Assessment and amelioration of hyperacusis in tinnitus patients. Acta Otolaryngol. 2005; 125(5):503-9. [CrossRef]

8. Nelting M, Rienhoff NK, Hesse G, Lamparter U. [The assessment of subjective distress related to hyperacusis with a self-rating questionnaire on hypersensitivity to sound]. Laryngorhinootologie. 2002;81(5):327-34. [CrossRef]

9. Bläsing L, Goebel G, Flötzinger U, Berthold A, KrönerHerwig B. Hypersensitivity to sound in tinnitus patients: An analysis of a construct based on questionnaire and audiological data. International Journal of Audiology. 2010;49(7):518-26. [CrossRef]

10. Beck AT, Epstein N, Brown G, Steer RA. An inventory for measuring clinical anxiety: psychometric properties. Journal of consulting and clinical psychology. 1988;56(6):893. [CrossRef]

11. Ulusoy M, Sahin NH, Erkmen H. The Beck Anxiety Inventory: Psychometric Properties. Journal of cognitive psychotherapy: An international quarterly. 1998;12:2.

12. Karasar N. Bilimsel arastırma yöntemi, (21. Basım). Nobel Yayın Dağıtım: Ankara. 2010.

13. Deryakulu D, Büyüköztürk Ş. Epistemolojik İnanç Ölçeğinin Faktör Yapısının Yeniden İncelenmesi: Cinsiyet ve Öğrenim Görülen Program Türüne Göre Epistemolojik İnançların Karşılaştırılması. Eğitim Araştırmaları. 2005;5(18):57-70.

14. Blomberg S, Rosander M, Andersson G. Fears, hyperacusis and musicality in Williams syndrome. Res Dev Disabil. 2006;27(6):668-80. [CrossRef] 
15. Jüris L, Ekselius L, Andersson G, Larsen HC. The Hyperacusis Questionnaire, loudness discomfort levels, and the Hospital Anxiety and Depression Scale: A crosssectional study. Hearing, Balance and Communication. 2013;11(2):72-9. [CrossRef]

16. Fioretti A, Tortorella F, Masedu F, Valenti $M$, Fusetti $M$, Pavaci S. Validity of the Italian version of Khalfa's questionnaire on hyperacusis. Acta Otorhinolaryngol Ital. 2015;35(2):110-5.

17. Fackrell K, Fearnley C, Hoare DJ, Sereda M. Hyperacusis Questionnaire as a Tool for Measuring Hypersensitivity to Sound in a Tinnitus Research Population. Biomed Res Int. 2015;2015:290425. [CrossRef]

18. Meeus OM, Spaepen M, Ridder DD, Heyning PH. Correlation between hyperacusis measurements in daily ENT practice. Int J Audiol. 2010;49(1):7-13. [CrossRef]

19. Baguley DM. Hyperacusis. JRSocMed. 2003;96(12):582-5. [CrossRef]

20. Formby C, Sherlock L, Gold S. Adaptive plasticity of loudness induced by chronic attenuation and enhancement of the acoustic background (L). The Journal of the Acoustical Society of America. 2003;114(1):55-8. [CrossRef]

21. Jastreboff P, Hazell J. A neurophysiological approach to tinnitus: clinical implications. Br J Audiol. 1993;27(1):717. [CrossRef]

22. Blaesing L, Kroener-Herwig B. Self-reported and behav- ioral sound avoidance in tinnitus and hyperacusis subjects, and association with anxiety ratings. International Journal of Audiology. 2012;51(8):611-7. [CrossRef]

23. Juris L, Andersson G, Larsen HC, Ekselius L. Psychiatric comorbidity and personality traits in patients with hyperacusis. Int J Audiol. 2013;52(4):230-5. [CrossRef]

24. Schaaf H, Klofat B, Hesse G. [Hyperacusis, phonophobia, and recruitment. Abnormal deviations of hearing associated with hypersensitivity to sound]. HNO. 2003;51(12):1005-11. [CrossRef]

25. Sammeth CA, Preves DA, Brandy WT. Hyperacusis: case studies and evaluation of electronic loudness suppression devices as a treatment approach. Scand Audiol. 2000;29(1):28-36. [CrossRef]

26. Anari M, Axelsson A, Eliasson A, Magnusson L. Hypersensitivity to sound: Questionnaire data, audiometry and classification. Scandinavian audiology. 1999;28(4):21930. [CrossRef]

27. Axelsson A, Hamernik R. Acute acoustic trauma. Acta oto-laryngologica. 1987;104(3-4):225-33. [CrossRef]

28. Brandy WT, Lynn JM. Audiologic findings in hyperacusic and nonhyperacusic subjects. American Journal of Audiology. 1995;4(1):46-51. [CrossRef]

29. Sheldrake J, Diehl PU, Schaette R. Audiometric characteristics of hyperacusis patients. Front Neurol. 2015;6:105. [CrossRef] 


\section{Appendix 1}

\section{Hiperakuzi Ölçeği}

Adınız:

Soyadınız:

Cinsiyet: Erkek / Kadın

Yaş:

Meslek veya okuduğunuz bölüm:

Yaşadı̆̆ınız yer:

Telefon:

Gürültüye maruz kalıyor musunuz ya da kaldınız mı?

Birkaç sene öncesine göre gürültüye tahammülünüz daha mı az?

Hiç işitme sorununuz oldu mu? Eğer olduysa, ne tür bir sorundu?

\section{Aşağıdaki ankette size en uygun olan yanıtı çarpı ile işaretleyiniz:}

1. Gürültü algısını azaltmak için kulak tıkacı ya da kulaklık kullandığınız oldu mu (anormal yüksek sese maruz kaldığınız durumlardaki kulak koruyucusu kullanımınızı dikkate almayınız)?

2. Günlük yaşamda, etrafınızdaki seslere kayıtsız kalmakta zorlanır mısınız?

3. Sesli veya gürültülü ortamlarda okumakta zorlanır mısınız?

4. Gürültülü ortamlarda dikkatinizi toplamakta zorlanır mısınız?

5. Gürültülü ortamlarda konuşmaları takip etmekte zorlanır mısınız?

6. Tanıdığınız birinin size, gürültüye ya da belli seslere tahammül edemediğinizi söylediği hiç oldu mu?

7. Sokak gürültüsüne karşı özellikle hassas mısınız ya da sizi rahatsız eder mi?

8. Bazı sosyal durumlarda sesleri rahatsız edici bulur musunuz (düğünler, barlar, konserler, havai fişek gösterileri)?

9. Birisi size bir şeyler yapmayı teklif ettiğinde (dışarı çıkmak, sinemaya ya da konsere gitmek vb.) ilk aklınıza gelen katlanmak zorunda kalacağınız gürültü mü olur?

10. Karşılaşacağınız gürültüden çekinerek, bir daveti geri çevirdiğiniz ya da dışarı çıkmaktan vazgeçtiğiniz olur mu?

11. Sessiz olan bir ortamda karşılaştığınız gürültü ya da belli sesler, sizi nispeten sesli olan bir ortamdakinden daha mı çok rahatsız eder?

12. Stres ve yorgunluk, gürültüde dikkatinizi toplama yeteneğinizi azaltır mı?

13. Günün sonuna doğru gürültüde dikkatinizi toplamakta zorlanır mısınız?

14. Gürültü ve bazı sesler sizde stres ve rahatsızlığa neden olur mu?

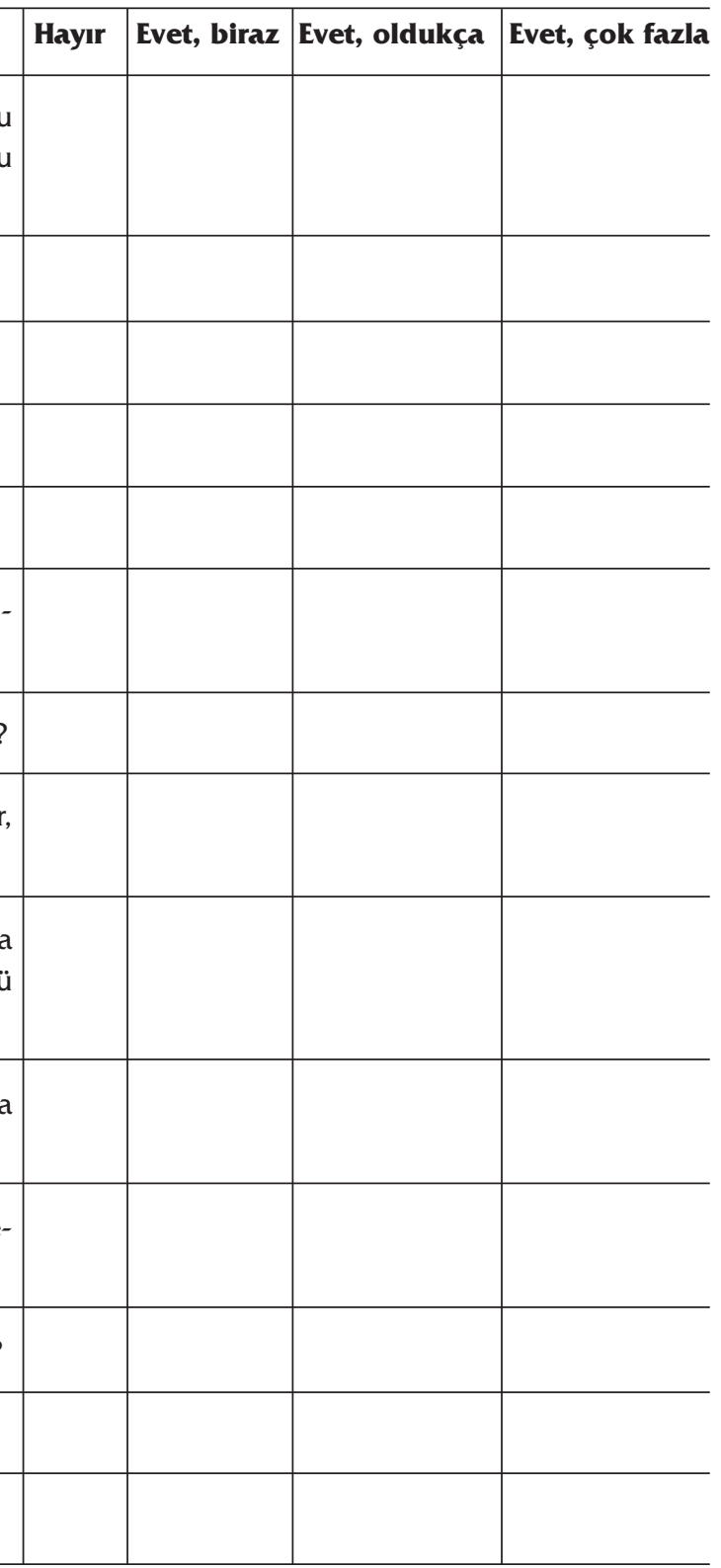

